\title{
Novelties and Consistence in the New Minor Offense Law of Hungary
}

\author{
BY GergÖ CzÉDLI*
}

\begin{abstract}
This article attempts to present an overview of Hungary's $3^{\text {rd }}$ generation legislation in minor offenses. Historical references are invoked only if ultimately necessary either for better understanding, or to appreciate the contrast between current provisions and former rules, but usually the paper does not look back any further than the previous act.

After a short introduction aimed at comprehending the subject itself, the article presents the concept published by the government, to see what goals it had and to realize how much it has subsequently achieved. The concept and a very short history are followed by a general overview of the new Act as a whole. Chapters 4,5 and 6 focus on the most fundamental changes, novelties, arguable or simply strange provisions, taking into consideration the substantive, procedural and executional regulations. As disputes arise, I also try to show what, sometimes controversial, solutions legal practice can offer, and to indicate where and how the legislature should consider amending the Act. A deeper theoretical and constitutional background has been omitted, as the paper strongly focuses on a practical approach.

The admitted purpose of the new Act was to speed up the procedure, accompanied by the hidden, although obvious aim of strengthening deterrence. None of these are fulfilled completely, yet considerable steps have been taken. The reason of partial failure is often within the Act itself, this position will be argued in this paper.

Keywords: minor offense law, Hungary, criminal law, criminal procedure
\end{abstract}

\section{INTRODUCTION AND VOCABULARY}

Unlike common law systems, Hungarian minor offenses into which this article tries to give an insight, are not, by any means, part of either criminal law, or criminal procedure. The first modern criminal codes of Hungary divided criminal offenses into three categories: felonies, misdemeanors and contraventions (or trespasses), where different substantive provisions applied to the latter. ${ }^{1}$ Procedural rules were essentially universal, ${ }^{2}$ although most contraventions did not fall within the jurisdiction of royal courts, rather in the competence of police and other administrative authorities, and a simplified, summary process applied. This system dramatically changed during the communist era when the contravention as a legal category was suddenly abolished, and some conducts that constituted a contravention were treated as a felony, while most of them became minor offenses. ${ }^{3}$

This separation was emphasized by changes in terminology as well. Following the Soviet trend, a new word was created within the nascent field of law that included the substantive and procedural provisions governing human conduct not considered to be a criminal offense. Rather this behavior was punished by the punitive power of the state, originally, exclusively via non-judicial organs and, initially, only by a fine. The appropriate term 'szabálysértés' literally means a violation of a rule, which is usually circumscribed in

* Judge, District Court of Szeged. E-mail: czedligergo@gmail.com

${ }^{1}$ Act V of 1878 on the Hungarian Criminal Code of Felonies and Misdemeanors and Act XL of 1879 on the Hungarian Criminal Code of Contraventions.

2 Act XXXIII of 1896 on the Penal Procedure.

${ }^{3}$ Decree Law No. 17 of 1955. Misdemeanors were turned into felonies for a short while as well, but criminal law soon returned to the dual system. 
EU legislation as an act punishable under the (national) law by virtue of being an infringement of the rules of law. ${ }^{4}$ Soviet influence on this area of the law has long since been removed, however, the German term n 'Ordnungswidrigkeit' is considered to be the closest in meaning. ${ }^{5}$ Finding, an appropriate English term is more difficult, due to the lack in any common law counterpart and any generally accepted definition. 'Misdemeanor' would be confusing, as the translation of the Hungarian criminal code uses this expression for less dangerous criminal offenses. ${ }^{6}$ 'Administrative offense' would also be a bit confusing as Hungarian minor offense law, in its current form, exceeds the realm of public administration and judicial organs play an increasing role. 'Trespass' or 'contravention' would also be wrong, as both refers to an extinct, third class of criminal offenses, as presented above. 'Petty' or 'minor' offenses are synonyms; to avoid any further confusion for those unfamiliar with Hungarian legal system or language, this article consequently uses the latter, implying that these offenses are indeed minor in comparison to criminal ones. ${ }^{7}$

\section{HISTORY AND CONCEPT}

Throughout the previous regime, and with some amendments even in the 1990's, minor offense law was governed by Act I of 1968. Although recent Hungarian legislation has been targeted by much domestic and international criticism, ${ }^{8}$ the $3 \mathrm{rd}$ minor offense code, Act II of 2012 (hereinafter: 'Szabs. $t$.') was certainly not enacted due to the fact that the country has been led by a new, right-wing government since 2010. Evidence of this assumption is simple: its predecessor, Act LXIX of 1999 ('Sztv.' for the distinction) was enacted by the first government; led by same prime minister and his party. The conservative ideological has remained virtually untouched, additionally the social-economic changes of one decade do not necessarily indicate that such a step as the introduction and adoption of a completely new code is justified.

As for the ideological background, the new government took considerable steps towards creating stricter provisions in the field of criminal law with more severe punishments and multiple sanctions against crime-repeaters. ${ }^{9}$ This approach logically had some impact on minor offense law. Transparency has never been a quality of Hungarian law-making, and it has not improved much recently. Despite this position we are not completely in the dark when it comes to law-making as the government published a

${ }^{4}$ See Council Framework Decision 2005/214/JHA art 1 (a) (iii).

5 Although 'Ordnungswidrigkeiten' are not punished by confinement in Germany and fines may not be turned into confinement either.

${ }^{6}$ Act $\mathrm{C}$ of 2012 on the Criminal Code (hereinafter 'Btk.') s. 5 divides criminal offenses into felonies and misdemeanors. (The English text can be downloaded from: http://www.academia. edu/4602286/Criminal_Code_of_Hungary_2012).

${ }^{7}$ Gábor Máthé introduced the term 'infraction' in his essay on the $2^{\text {nd }}$ generation legislation on the field but it has not become widespread, see Máthé (2006) 131.

${ }^{8}$ See a few examples at: http://content.time.com/time/world/article/0,8599,2103775,00.html, http://www.bloomberg.com/news/articles/2013-06-14/orban-constitution-threatens-hungary-lawsexperts-says, http://www.nytimes.com/2011/04/19/world/europe/19iht-hungary19.html?_r=0, http:// www.theguardian.com/commentisfree/libertycentral $/ 2012 / \mathrm{mar} / 13 /$ hungary-fundamental-law-eu, http://www.ft.com/intl/cms/s/0/004ac47c-68ed-11e0-9040-00144feab49a.html\#axzz3QNqHvFOH.

9 See Btk., and previous amendments of the former Act IV of 1978. 
surprisingly detailed preparatory study on the subject on 12 July, 2011. The government's Concept gives a deep analysis of the previous minor offense's act which was still in force, and sets the purpose of creating a "procedural system that ensures the opportunity of an effective and efficient process for the authorities." 10 The aim of this goal, which subsequently could be read in the preamble of the Szabs. tv., suggests that the concept is a revision of the competence of authorities, the definitions of minor law offenses and the system of sanctions. ${ }^{11}$

In detail, the Concept had first of all suggested that all substantive, procedural and enforcement regulations be included in one single act, which achieved later.$^{12}$ This conceptual change also entailed that any conduct can now be declared a minor offense in an act of law. ${ }^{13}$ Additionally local governments have lost their traditional right to rule minor offenses in local regulations.

According to the Sztv., the general authority acting in minor offense cases was the local government. ${ }^{14}$ The Concept suggested the competence of the notaries be transferred to either a brand new authority or to the relatively new county government offices. The legislature subsequently chose the latter, thus centralizing this part of the public administration. ${ }^{15}$

When evaluating sanctions, the Concept considered the executional rules of the Sztv. To be complicated. ${ }^{16}$ The Concept suggested that confinement, a short term imprisonment, originally intended for offenders of certain minor offenses, should not only be applicable to the most severe minor offense penalty, but recidivists should be punished with the said penalty in case of any minor offense.${ }^{17}$ Despite preliminary protests,${ }^{18}$ as we will see below, this idea was realized. The Concept also stated that fines were relatively low by European comparison, thus they should be raised. ${ }^{19}$ It proposed the introduction of 'fix' fines for certain minor offenses that should be imposed without any discretion; and a broader

10 Concept for the Comprehensive Review of the Act on Minor Offenses (hereinafter: the 'Concept') Point 2. Available at: http://www.google.hu/url? sa=t\&rct=j\&q=\&esrc=s\&source=web\&cd $=4 \&$ ved $=0$ CDUQFjAD\&url $=$ http $\% 3 \mathrm{~A} \% 2 \mathrm{~F} \% 2 \mathrm{~F} 2010-2014$. kormany.hu $\% 2 \mathrm{Fdownload} \% 2 \mathrm{~F} 6 \% 2 \mathrm{~F} 18 \%$ 2F40000\%2FKoncepci\%25C3\%25B3.doc\&ei=a_0GVIKPGYaaygO0zoDIAg\&usg=AFQjCNHOdKv jvTUYESKzn8n512EydZbaEQ\&sig2=Mdsc6Pr3Wxh1 VpSXhpUIgw\&bvm=bv.74115972,d. bGQ\&cad=rja (03-09-2014).

11 Concept 2.

12 The Sztv. only included general substantive rules and some of the specific definitions of minor law offenses in addition to procedural and enforcement provisions, while most of the definitions were in regulations and local regulations. Most important among these was Government Regulation No. 218 of 1999 (28 Dec.) on Certain Minor Offenses.

13 Szabs. tv. s. 1 (1).

14 The notary thereof, to be more precise; Sztv. s. 32 (1).

15 Szabs.tv. s. 38 (1); Chapter 5.2.

${ }^{16}$ Concept 5.1.

17 Concept 5.2.

18 Opinion of the Hungarian Civil Liberties Union on the comprehensive review of the act of minor offenses. II.3. Available at: tasz.hu/files/tasz/imce/szabalysertesi_koncepcio-velemeny_pdf accessed 23 October 2014.

19 Concept 5.3.1. The document seems to forget the gap between West-European and Hungarian wages. 
application of summary fines..$^{20}$ Finally, the document also sought to introduce a new form of penalty: community service work, ${ }^{21}$ which earlier had not been a minor offense penalty at all, only a means by which to enforce the imposition of fines. ${ }^{22}$

As for procedural matters, the Concept considered legal remedies an obstacle to achieving an expedited process. In some circumstances the courts could adjudicate upon an objection (a special legal remedy) concerning the decision of a minor offense authorities. As such this process could be considered a form of appeal. Sztv. set out that courts should administer decision without holding a hearing. Once the decision had been delivered, upon the motion of the defendant, they should have held a trial, usually to announce the very same decision. ${ }^{23}$ According to the Concept, the court itself should decide whether to hold a trial, and the conclusive decision would be subject to no further appeal. ${ }^{24}$

The last exceptional chapter of the Concept of the government focused on the execution process. I wholeheartedly agree with first sentence set out in the Concept: 'Rules of enforcement are required to be rethought, primarily to simplify the process. ${ }^{25}$ I have chosen to omit certain aspects of the Sztv. as they would distract us from our subject, however, it is worth mentioning that in case a perpetrator failed to pay a few thousand Forints of fine voluntarily, the enforcement often lasted for over a year. ${ }^{26} \mathrm{~A}$ possible solution, urged by the Concept was to keep the former tax-enforcement system on minor offense fines, while reforming it for efficiency's sake. Unfortunately, the document lacks detailed suggestions, except that it might be advisable to trust bailiffs instead of the tax offices of the local governments, as the latter tends not to be sufficiently motivated. ${ }^{27}$ Another idea targeting traffic infringements suggested that fines imposed in these circumstances should be transferred to a driving ban; while in other cases, transforming to community service work would be favorable over confinement. ${ }^{28}$ With regards to the actual costs of confinement, it should only be applied if tax-enforcement and community service work fails, and the 'social dangerousness' of the minor offense justifies it. ${ }^{29}$

\section{THE CURRENT ACT II OF 2012 AND ITS AMENDMENTS}

Although the reception of the Concept was rather positive, the Szabs. $t v$. published on 6 January 2012, entered into force on 15 April 2012 and contradicted the Concept on many points. According to the assumed intentions of the legislature, the four months period prior to entering into force would have been an appropriate time for preparation; the Act was,

20 Concept 5.3.2.

21 Concept 5.4.

22 Namely, if the perpetrator failed to voluntarily pay the fine, and the tax-enforcement process was unsuccessful, the authority would transform it into community service work, upon the perpetrator's consent, and in case the local government could offer such a job [Sztv. s. 111 (1)-(6)].

23 Sztv. s. 94 (1) and (4), 95 (5).

24 Concept 6.

25 Concept 7.

26 See Note 22; for further details see Chapter XII of Sztv. and Section 111 thereof in particular; for practice and criticism: Gergő Czédli, 'A szabálysértési jogorvoslati rendszer és bíráskodás rövid története' (2014) available from the official page of the Association of Hungarian Judges at <http:// www.mabie.hu/node/2165> accessed 23 October 2014.

27 Concept 7.1. Half of the fine was the income of the local tax office, which should have been motivationenough.

28 Concept 7.1.1; 7.2.

29 Concept 7.3. 
however, thoroughly amended by Act XXXI of 2012, which was published on $13^{\text {th }}$ of April 2012 and entered into force on the subsequent day. Therefore, legal professionals and the wider public only had two days to learn the new rules and to prepare for their application.

The text of the Szabs. tv. was inconsistent and suffered from numerous amendments, 23 in total right up until the closure of the manuscript. ${ }^{30}$ Most of these amendments were fortunately technical or of otherwise lesser importance, however despite this it is still almost impossible to find a section unchanged. This fact alone seems to undermine legal certainty.

Most crucial changes to the Sztv. and often to the Concept are to be seen in the following chapters of this paper. It is worth noting at this point that the text was of a shockingly low quality when it entered into force. Different wording and false construction of sentences in certain parts of the text, using sometimes a different legal term for the same thing is regrettably common throughout the Act. It is also easy to identify definite parts copied from the previous act which have been left unchanged. Additionally the legislature often failed to adjust to the already heterogeneous context. ${ }^{31}$ As some provisions contradict others, and some are obscure or pointless, the new law naturally created some confusion. ${ }^{32}$

At this point it is also worth adding that I agree with the statements of László Bisztriczki and Péter Kántás that the explanatory notes of the government do not provide any assistance with their tautological statements. ${ }^{33}$

Despite all its flaws, the Act completely fulfills one of the Concept's goals: it includes all basic substantive, procedural and executional rules of the field; regulations of the Government and the Ministry of Domestic Affairs contain only minor, implementing rules. ${ }^{34}$ The Act in its current form consists of 6 parts, 31 chapters and 254 sections, which, unlike most Hungarian sources of law, are divided into 208 numbered titles. The parts

30 Manuscript closed on $13^{\text {th }}$ March 2015. List of further acts amending Szabs. tv.: Act LXVI of 2012, Act XCV of 2012, Act CXVI of 2012, Act CLXXXI of 2012, Act CLXXV of 2012, Act CCXXIII of 2012, Act XXI of 2013, Act LXXI of 2013, Act CXXXIII of 2013, Act XCIII of 2013, Act CXLIX of 2013, Act CXCII of 2013, Act CCII of 2013, Act CCL of 2013, Act CLXXXVI, Act CCXXXIX of 2013, Act CCXLV of 2013 and Act LXXII of 2014. In addition to these amendments, Decision 38 of 2012 (14 Nov.) of the Constitutional Court annulled Section 186 of the Szabs. tv.

31 Czédli (2014c) 9.

32 One example of misusing legal terms is that the original version of the text describes the exact content of the court's decision as follows: without a hearing the court may 'impose a penalty' on the defendant; at a hearing it may 'establish his liability and impose a penalty' (i.e. it is necessary to establish what is needed to be drafted in the disposition too); while in a so called accelerated procedure it may 'convict him as guilty' of a minor offense and impose a penalty. The first two options show only a minor incoherence, however, the third one did shock experts of the field, as in the Hungarian legal system, the term 'guilty' is used exclusively in criminal procedure, and it has always been alien to minor offense law. Moreover, neither the Act, nor its explanatory notes gave any reason, why the defendant would be 'guilty' in an accelerated procedure when otherwise he is not deemed guilty of the same minor offense, even if he actually had committed it. This very problem has been subsequently solved by an amendment, namely Act XCIII of 2013 s. 187.

33 Bisztriczki (2012) 26.

34 Namely: Ministry of Domestic Affairs Regulation No. 21 of 2012 (13 Apr.) on handling data for the minor offense records; Ministry of Domestic Affairs Regulation No. 22 of 2012 (13 Apr.) on miscellaneous aspects of implementing the Szabs. tv. that focuses mainly on the procedure of the police; Ministry of Domestic Affairs Regulation No. 17 of 2012 (5 Apr.) on executing minor offense confinement; Ministry of Domestic Affairs Regulation No. 73 of 2013 (18 Dec.) on mediation in minor offense cases; and Government Regulation No. 63 of 2012 (2 Apr.) on fix fines. (These are not the official titles, only their essence.) 
follow each other in a logical order: general rules, procedural rules, execution, registration system, definitions of minor law offenses and final provisions. This paper can only deal with a few of these elements of the Act such as the general substantive, procedural and enforcement provisions, due to its limited space.

\section{BASIC SUBSTANTIVE PROVISIONS}

It is a widely accepted opinion that the new Minor Offense Act shows a significant convergence with criminal law, which resulted in 'an independent field of law that is not (yet) part of criminal law, but keeps creeping towards it. ${ }^{35}$ As for independence, Róbert Ferenc Belcsák remarks that changes 'altogether indicate the very tendency that the relevant legislation slowly loses its autonomy as a field of law. ${ }^{36}$

The Act itself starts with the definition of the term 'minor offense' meaning any activity or omission that is punishable under the Szabs. $t v$. and that is considered potentially dangerous to society, ${ }^{37}$ which mutatis mutandis complies the definition of a criminal offense. ${ }^{38}$ Similarity is obvious in the definition of 'social dangerousness' as well, as it is considered a conduct which prejudices or presents a risk to the person or rights of others, or the fundamental constitutional, economic or social structure of Hungary provided for in the Fundamental Law, on a smaller scale than a criminal offense. ${ }^{39}$

Hungarian minor offense law is traditionally considered a mixed area as minor offenses cover two major fields of different origin and character. Criminal type minor offenses are petty crimes, lesser forms of often well known criminal offenses such as theft or fraud, where either only the amount of damage separates a minor offense from a criminal one, or some other objective factor can make a distinction. ${ }^{40}$ The other branch consists of administrative offenses, infringements of other branches of law having no criminal offense variant, which usually do not directly hurt another persons' rights, only to some extent, the interests of public administration by violating administrative rules. While the said definition of Szabs. $t v$. accurately describes criminal types of minor offenses, it hardly applies to usually negligent conduct constituting administrative offenses. For instance, it is hard to find any danger to society in bathing in a forbidden area, ${ }^{41}$ which is by any means comparable to the potential threat of a criminal offense. Anyway, it is not the only trait of the Act that shows convergence with criminal law. The Act does not waste much time on substantive law principles and guarantees. Despite this it might be worth mentioning that at a substantive level the same principles apply as they do in criminal law.

Sztv. referred to the Criminal Code when defining basic notions, like intent or attempt, and so does the new Act, therefore there is no fundamental change at this level. ${ }^{42}$ Unless the Act provides otherwise, either intentional or negligent perpetration shall be punishable. ${ }^{43}$

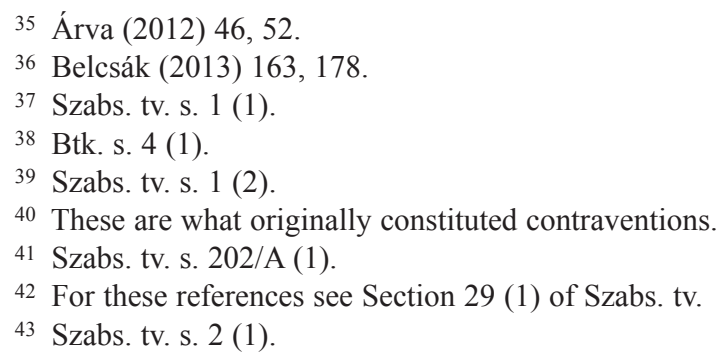


This is a marked difference to criminal law, where criminal offenses are usually intentional conduct, and negligent conduct only constitutes a criminal offense when the Criminal Code expressively renders it so. ${ }^{44}$ The responsibility of the instigator and aider shall be established as specified in the Criminal Code. ${ }^{45}$ The defendant is only responsible for attempt where the Szabs. $t v$. declares it punishable for a specific act. ${ }^{46}$ Preparation always remains unpunished, as the Act does not specify any provision for this . The criminal law variants of perpetrator, such as 'joint' and 'indirect' perpetrator were not in use in the Sztv. And neither by its entry into force. The Szabs. $t v$., introduced them through an amendment, referring again to the Criminal Code. ${ }^{47}$ Prior to that, the offender was considered a perpetrator, irrespective of whether he had acted on his own, jointly with others or via3 persons, who due to minority, insanity or coercion may not have been held responsible.

The new Act introduces a new penalty system too, somewhat unprecedented. Sanctions are still divided into penalties and measures. As for penalties, the Act simply doubled the maximum of financial penalties for minor offenses also punishable with confinement, ${ }^{48}$ while the maximum period of confinement, which may still be imposed exclusively by courts, remained untouched. ${ }^{49}$ As a new and third form of penalty, community service work may also be imposed for a minimum period of six, and a maximum period of 180 hours. ${ }^{50}$ The latter may, however, only be imposed upon the consent of the defendant. ${ }^{51}$

There have been changes to measures as well. The driving ban is not a new form of the measure, yet in the former Act it was only applicable for certain minor offenses when the law expressively allowed it. ${ }^{52}$ Now courts and other authorities may apply a driving ban for an unchanged maximum period of 12 months whenever the minor offense was committed by violating traffic rules whilst driving a vehicle, in case the driving thereof is subject to a license. ${ }^{53}$ Moreover, the defendant shall be banned from driving in certain cases. ${ }^{54}$ The rules of confiscation, warning and the seldom applied prohibition from residing in a particular area have remained constant. ${ }^{55}$

Another strange novum of the new Act is the abolition of special maximum amounts of financial penalties. The Sztv., not only specified a general minimum and maximum amount or period for each form of punishment, but a specific maximum amount of fine for each minor offense. For example the minor offense 'minor infringement of traffic regulations' should have been fined with up to $30000 \mathrm{Ft},{ }^{56}$ yet currently the general maximum amount of $150000 \mathrm{Ft}$ applies for the same minor offense, which is a fivefold increase in this case.

44 Btk. s. 4 (1).

45 Szabs.tv. s. 2 (2); Btk. s. 14.

46 Szabs. tv. s. 2 (3); Btk. s. 10 (1).

47 Szabs. tv. s. 29 (3); Act XCIII of 2013 s. 127.

48 To $300000 \mathrm{Ft}$ (approximately $1000 €$ ); Szabs. tv. s. 11 (1).

4960 days, as stipulated in Szabs. tv. s. 9 (2); or 90 days as a cumulative sentence [Szabs. tv. s. $22(1)]$.

50 Szabs. tv. s. 14 (1)-(2).

51 Szabs. tv. s. 104 (3), $120(5)$.

52 Sztv. s. 18 (1).

53 Szabs. tv. s. 16 (1) (4).

54 Szabs. tv. s. 16 (1a).

55 Szabs. tv. s. 18, 20 and 19.

56 Government Regulation 218 of 1999 s. 54 (1). 
The Act gives detailed regulations applicable to minor offense repeaters. If the liability of the defendant has been established at least twice within 6 months for minor offenses punishable by confinement, prior to the third minor offense committed, the maximum period of confinement shall be 90 days, provided that the last minor offense is punishable by confinement as well. ${ }^{57}$ If the defendant has been convicted for either at least two minor offenses punishable by confinement, or for at least two minor offenses not punishable by confinement, the third minor offense committed within 6 months that is otherwise not punishable by confinement, shall be punishable by a confinement of a maximum period of 75 or 60 days, respectively. ${ }^{58}$ Finally, if the two or more prior convictions are for minor offenses not punishable by confinement, yet the third minor offense within 6 months is punishable, the maximum period of confinement shall be 75 days ${ }^{59}$ It is important to note that these rules do not apply to summary fines and traffic infringements. ${ }^{60}$ Courts, fortunately, are not obliged to impose confinement in the said cases, they only have the legal opportunity to, which is rarely used. Still, in theory, it is possible to be punished for 60 days in prison on grounds of these rules for any minor offense if someone is adequately notorious.

On reading the last paragraph carefully one might ask, what special rules of punishment shall apply to defendants having committed one minor offense that is punishable by confinement and another one that is not. Surprisingly, none, as the legislature, most probably unintentionally, left that option out of the Act, which is another typical example of the quality of the Act.

As the Concept proposed ${ }^{61}$ the Act also introduced 'fix' fines, although they are perhaps not as fixed as the legislature meant them to be. The Szabs. $t v$. itself provides that the government may, in a regulation, set forth the amount of fines that shall be applied for certain traffic minor offenses without further consideration. ${ }^{62}$ Details are given in Government Regulation No. 63 of 2012 (IV.2.) and in annexes 1 to 9 thereof, which are basically lists rendering certain amounts of fines for the violation of traffic regulations specified therein. ${ }^{63}$ Police authorities apply these rules consequently and without hesitation, courts, however, are way more reluctant, due to their different approach.

This leads us to the issue of imposing penalty. Although the wording of the Szabs. $t v$. is, as usual, less precise, than should be, the form and amount or period of punishment imposed or measure applied shall be adjusted to the seriousness of the minor offense and the personal circumstances of the defendant. ${ }^{64}$ The text does not expressively refer to the aim of punishment, as criminal law does, ${ }^{65}$ and also omits traditional factors, like the degree of culpability, or the danger the perpetrator represents to society. Judicial practice, however, keeps using the very same system of aggravating and mitigating circumstances, which has

57 Szabs. tv. s. 23 (1) a).

58 Szabs. tv. s. 23 (1) b) and d).

59 Szabs. tv. s. 23 (1) c).

60 Szabs. tv. s. 23 (2) a) b).

61 See note 20.

62 Szabs. tv. s. 11 (3).

63 The summary fine is always the half of the 'normal' financial penalty, so it is usually wiser to accept the fine immediately.

64 Szabs. tv. s. 21 (1).

65 General and special deterrence, to put it simply; see Btk. s. 79. 
served well for decades if not centuries in criminal law. ${ }^{66}$ As for further rules on imposing penalty, in the case of a minor offense which is punishable by confinement, the court may impose any penalty or apply any measure. In the case that it is not punishable, the court or the competent authority may still impose any penalty except for confinement or apply any measure ${ }^{67}$ These, otherwise rational, rules clearly contradict the obligation of imposing an amount of fine defined by the said Government Regulation for certain minor offenses.

Courts resolve this dilemma as follows: overruling minor offense decisions upon the objection of the defendant, they may not change the amount of fine if the minor offense shall be punishable by a defined amount of fine. ${ }^{68}$ After a thorough examination of all relevant facts and circumstances, the Court may decide to impose another form of penalty or apply a measure instead of the fine when it seems appropriate. The point of the courts is that due to the hierarchy of the legal system itself, a government regulation may not contradict the provisions of an act of law, thus the above-mentioned government regulation, upon authorization of the Szabs. tv. and Section 11 (3) thereof, may only define the amount of fine for these cases. This section may not, however, alter the free system of penalties and measures provided by the Act any further than the legal authorization of the Act implies, meaning that except for confinement, that any penalty may be imposed and any measure may be applied. ${ }^{69}$

It is finally worth mentioning that lighter rules apply to juveniles, in whose cases not only community service work, but financial penalty may be only imposed upon consent. ${ }^{70}$ Imposing confinement does, however, not require the consent of juvenile defendants, although the said stricter rules for repetition do not apply to them. ${ }^{71}$ The maximum period of confinement and maximum amount of fine are also reduced. ${ }^{72}$ It is another question whether confining juveniles for minor offenses, even for a decreased period of time, can be justified at all, for it is arguable from a children's rights' standpoint, that their confinement could possibly violate Article 37 (b) of the UN Convention on the Rights of the Child. ${ }^{73}$ Upon the motion of the ombudsman, the Constitutional Court dealt with the children's rights problem, and after a majority vote it considered these provisions of the act compatible with the Fundamental Law. ${ }^{74}$ The Constitutional Court argued that although the Convention allows the imprisonment of a juvenile as an ultima ratio and when it is proportionate, these requirements are met because confinement is only imposed when it is ultimately necessary with regard to the seriousness of the minor offense and the personal circumstances of the defendant. ${ }^{75}$ I wonder what minor offense would impose such danger to society and agree with the minority opinion of Miklós Lévay that the imprisonment of a juvenile should only be justified by a serious criminal offense. ${ }^{76}$

${ }^{66}$ Btk. s. 80 (1); details on aggravating and mitigating circumstances can be learnt from, above all, Opinion No. 56 of the Criminal Chamber of the Supreme Court (BKv. 56).

${ }^{67}$ Szabs. tv. s. 21 (3)-(4).

68 Szabs. tv. s. 105 (1).

${ }^{69}$ District Court of Csongrád 10.Szk.893/2013/2.

70 Szabs. tv. s. 27 (3).

71 Szabs. tv. s. 27 (3).

72 Szabs. tv. s. 27 (2).

73 According to which, amongst others, the arrest, detention or imprisonment of a child shall be used only as a measure of last resort and for the shortest appropriate period of time.

74 Constitutional Court's Decision 3142/2013 (VII.16.)

75 Constitutional Court's Decision 3142/2013 (VII.16.) para 32.

76 Constitutional Court's Decision 3142/2013 (VII.16.) para 35-60. He is also right that there is no real alternative sanction, as a fine or community service work may only be imposed upon consent. 


\section{ESSENTIAL PROCEDURAL RULES}

\subsection{Principles}

Although I would not underestimate the importance of fundamental substantive law changes briefly presented in the previous chapter, the greatest impact on administration and citizens was made by the procedural regulations. Unlike the previous Act, the Szabs. tv. devotes a complete, though short chapter to basic provisions, which would be absolutely correct, if it was not for the fact that those provisions contradict other rules of the same Act.

Ex officio procedure, presumption of innocence, burden of proof, right against selfincrimination, right to use of the native language are clear and do not need any further explanation, ${ }^{77}$ they live up to common the minimum standards of human rights. The principle concerning independent judgment of minor offense liability means that the court and any authority dealing with minor offense cases are not bound by decisions adopted in other procedures. This is especially true in civil proceedings or disciplinary actions with the exception of any decision taken in a criminal procedure. ${ }^{78}$

The right to legal remedy is the only principle, I purposively omitted from the list above, as it is the only rule in this chapter that is very confusing so much so that there are still unresolved disputes concerning its interpretation. . First of all, the right to legal remedy, as a principle, is part of the Hungarian constitution as well, ${ }^{79}$ so any reference thereto would be no surprise. The actual section 35 of the Szabs. $t v$. states that a legal remedy is provided against any decision, measure taken by the court or the authority dealing with minor offense cases, or because of the failure of taking such measure, except as otherwise provided by the Act . The Sztv. did provide different forms of legal remedies versus certain, though crucial decisions, but as a main rule, any other decision or measure was subject to no legal remedy. Early commentaries claimed the new Act broke with this legal remedy system. ${ }^{80}$ Courts, however, soon realized that the issue of legal remedy and appeal is a 'diverse problem worth of further complex review.' ${ }^{\text {81 }}$ The real problem is that it cannot be decided, whether the said provision of the Act makes the right to appeal against the court's decision a general rule or not.

Considering certain decisions, the Act provides detailed regulations of the actual form of legal remedy, as well as the persons entitled thereto, the deadline, the competent authority or court examining that appeal or other request. For other decisions or measures (like a subpoena) any legal remedy is expressively excluded.

As a form of legal remedy, a complaint is general against any decisions of non-judicial minor offense authorities, so it is clear that, as a main rule, the defendant and, in certain cases, other participants of the proceedings may file a complaint if the Szabs. $t v$. does not expressively provide otherwise. ${ }^{82}$ Rules applicable to procedures carried out by courts are, unfortunately, way more obscure, as the legislature failed to draft any general rule defining either the general form of legal remedy against the court's orders, or the deadline, or even the competent court of second instance. The Act provides that the defendant, his

77 See Szabs. tv. s. 31 to 34 and 36.

78 Szabs. tv. s. 37.

79 Fundamental Law a. XXVIII (7).

80 Bisztriczki (2012) 109.

81 Nánási (2012) 50, 68.

82 Szabs. tv. s. 98 (1); the right to submit a complaint may also be excluded because another form of legal remedy applies, see the rules of objection in sub-chapter 5.4. 
representative, the police and, considering the damages, the victim may, file an appeal against an order promulgated at trial within 8 days. ${ }^{83}$ This rule only applies when the court administers a minor offense case at first instance, being punishable by confinement, so this cannot be considered a general rule. The question is how courts shall deal with situations when they are either not trying a minor offense punishable by confinement (they have other roles as we will see), or the order is simply not passed at trial, and the Act neither excludes the right to legal remedy, nor provides any possibility thereto. There is a grey zone in the Act, ${ }^{84}$ where one can say that there is no right to appeal, because the Act neither provides this right in any of its specific provisions, nor does it say that the general form of legal remedy for court's procedure is appeal. Additionally, the Act does not provide any second instance judicial authority when local courts are not acting in first instance minor offense cases. Alternatively, it is also possible to argue that the above-mentioned rules on appeal provided for first instance orders passed at trials shall be mutatis mutandis applied due to the principle of right to legal remedy.

Neither solution is perfect, as such incoherence of the Act cannot be solved by mere interpretation. Various amendments of the Szabs. $t$. excluded legal remedy for an increasing number of decisions, thus narrowing the scope to which the said problem occurs, however, the legislature failed to solve the problem itself by either amending the actual text of section 35 of the Act, or giving a universal right to appeal against court orders in the appropriate chapter.

Typical examples are when courts have difficulties in deciding whether to ensure a right to appeal or not, are orders on transmitting the case to the competent court, or on terminating the procedure, in case these decisions are not passed at trial, which often happens. As for the practice of courts, district courts usually chose to exclude the right of appeal, which I agree with, ${ }^{85}$ on grounds of interpretation following the logic written above. The conclusion reached by an educational material of the National Office for the Judiciary $(\mathrm{OBH})$ was identical. ${ }^{86}$

The dispute is still unresolved, because no matter how widespread this practice has become, the Curia has started to emphasize the opposite opinion in cases of designating the competent court due to conflict of competence, which is the only type of case the Curia can ever deal with concerning a minor offense. According to the position of the Supreme Court of Hungary, the Act does not have any provisions excluding the right to appeal against an order on transmission, so district courts unlawfully prevent it. ${ }^{87}$ Although the jurisdiction of the Curia in these cases includes only deciding on the competent court, the Criminal Chamber apparently considered this question crucial, as in a transcript it called the attention of lower courts to the advisable practice. ${ }^{88}$ Because of its further implications, district courts, which are independent and may not be instructed in this way, are still reluctant to apply this approach, resulting in a chaotic situation that most probably will not be resolved without an intervention by the legislature..$^{89}$

83 Szabs. tv. s. 121 (1).

84 Czédli (2014c) 11.

85 Czédli (2014c) 11.

86 Kahler (2012) available at <http://ejegyzet.hu/obh/szabalysertes/index.html> accessed 12 December 2013 2.4.6.

87 Curia Bkk.I.131/2014/2.

88 Vice-president of the Curia, 2014.El.II.E.1/11.

89 There is another way though: the Curia might also interfere for real, as under sections 32-44 of Act CLXI of 2011, a judicial uniformity procedure may be initiated if the development and 


\subsection{Competent Authorities of and Parties to the Procedure}

Prior to the entering into force of Szabs. $t v$., the general authority competent in minor offense cases was the notary of the local government. As can be seen, it was one conceptual purpose of the legislature to transfer this power to an authority under governmental control, which turned out to be the 20 county government offices, and the district offices. ${ }^{90}$ Although the default competent authority is the district office, in reality, the majority of minor offense cases still belongs to the competence of the police, ${ }^{91}$ as the number of traffic minor offenses significantly exceeds the total number of all others. The third authority is the National Tax and Customs Office, having competence over some financial minor offenses. Minor offenses punishable by confinement are tried by the district courts, as any deprivation of liberty shall be based upon a decision by court. ${ }^{92}$ The first instance procedure is always carried out by the district courts - the lowest level of the Hungarian judicial system -, thus the second instance procedure falls within the jurisdiction of the tribunals. ${ }^{93}$

Beside the said minor offense authorities, a number of other authorities or persons acting on behalf of public administration are entitled to impose a summary fine in the case of in flagrante delicto if the Act so provides. ${ }^{94}$

As no formal indictment is submitted and no sentence is passed, the defendant in minor offense law is not called a suspect, an accused or a convict, unlike as is the case in the criminal procedure depending on the phase of the process. ${ }^{95}$ Again to emphasize the distinction, Szabs. $t v$. uses the term 'person affected by the procedure' before a final decision has been passed, and 'perpetrator' instead of convict thereafter. ${ }^{96}$ This paper, however, keeps using the more clear term 'defendant' as an umbrella word.

Participation of a legal counselor is obligatory only in the so-called accelerated court procedure, otherwise the right to defense is restricted. The defendant may, at any time, give mandate to a representative that can strangely be not only a lawyer, but any adult person without a legal educational background. ${ }^{97} \mathrm{He}$ may not, however, with the exception of the accelerated procedure, ask the authority to appoint a legal counsel for acting on his behalf, as the Act does not have any provisions granting it.

The victim, if there is any, is also a party to the procedure, although being of lesser importance. The victim may exercise his rights either personally, or via a representative. ${ }^{98}$

uniformity of judicial practice requires the adoption of a judicial uniformity decision as a matter of principle. These decisions are binding on courts and play a really important role. In practice, they, however focus on criminal and civil law. The Curia have never passed such a decision concerning minor offense law.

90 See Note 15. These new organs have quite long names, like 'District Office of Szeged of the County Government Office of Csongrád'.

91 Szabs.tv. s. 38 (2).

92 Szabs. tv. s. 38 (3); Fundamental Law art 'N' (1)-(3).

93 Szabs. tv. s. 41 (1), 42 (1).

94 Szabs. tv. s. 39 (1)-(2).

95 Act XIX of 1998 on the Criminal Procedure (hereinafter: Be.) s. 43 (1).

96 Szabs. tv. s. 52 (1), 139 (1a); this terminology was identical in the previous act.

97 Szabs. tv. s. $53(1)$.

98 Szabs. tv. s. 54 (1), 55 (1). 


\subsection{The Administrative Procedure and its Legal Remedies}

The actual minor offense procedure starts upon a report or ex officio. ${ }^{99}$ Some specific minor offenses, like defamation, are punishable only upon the private motion of the victim; ${ }^{100}$ the lack of that motion leads to the rejection of the report or the termination of the procedure. ${ }^{101}$ Private motion may be subject to withdrawal, which is of course also a ground for termination. ${ }^{102}$

The authority shall reject the report within 8 days and without further proceedings if the facts therein constitute no minor offense, the person reported may not be punished on grounds specified by the Act (due to minor age, etc.), the procedure would violate the principle ne bis in idem, or the minor offense is statute-barred. ${ }^{103}$ Rejection is, however, no obstacle to confiscation. If there is no ground for rejection, the minor offense procedure shall be commenced and then finished within 30 days that may be subject to a one-time prolongation. ${ }^{104}$

The authority shall suspend the procedure till the clearance of preliminary questions, the result of mediation, or if the defendant is absconding or abroad. ${ }^{105}$ The procedure shall be terminated on grounds for the rejection of the report, or because of the lack of evidence, or if the mediation was successful, although the Act needlessly repeats here the same grounds in different words. ${ }^{106}$ Speaking of mediation, the legislature, to my surprise, amended the Act with meticulous provisions, ${ }^{107}$ granting impunity upon mutual consent of the defendant and the victim if the damages of the latter were compensated. Not only these bureaucratic rules contradict the expediency of the procedure, but the idea of possible impunity seems to undermine the most conservative approach of deterrence from the legislature's perspective. Probably it is no mistake to consider mediation in minor offense procedure an unexpected, small step toward restorative criminal justice. ${ }^{108}$

In those situations where all of the relevant facts and circumstances seem to be known and if it is considered appropriate by the authority they may pass a decision establishing liability and imposing a penalty without hearing the defendant or any other person. ${ }^{109}$ It shall be noted that the authority is free to decide whether to proceed in absentia, or to hear the defendant prior to taking a decision. As a legal remedy against this decision rendered in absentia, the defendant may motion his hearing within 8 days following the communication. ${ }^{110}$ In this case, the procedure practically restarts, and the authority shall interrogate the defendant and take any other evidential actions necessary.

99 Szabs. tv. s. 78 (1).

100 Szabs. tv. s. 79 (1), 180 (1).

101 Szabs. tv. s. 80 b), 83 (1) e).

102 Szabs. tv. s. 79 (6). It is also a difference in comparison to criminal law.

103 Szabs. tv. s. 80.

104 Szabs. tv. 81 (1)-(3).

105 Szabs. tv. s. 82 (1).

106 Szabs. tv. s. 83 (1).

107 Szabs. tv. s. 82/A-82/K; Act CLXXXVI of 2013.

108 This step was absolutely necessary to be taken. Mediation has been applied in criminal law for a long time, why should we exclude this option considering less dangerous minor offenses? Of course, mediation neither speeds up, nor simplifies the procedure, thus contradicting the original goals.

109 Szabs. tv. s. $102(1)$.

110 Szabs. tv. s. 103 (1). 
The evidential procedure follows a simplified pattern of a criminal procedure. At the beginning of his interrogation, the defendant shall be warned of his right to remain silent and not to incriminate himself. ${ }^{111}$ To the questioning of the witness, a warning on perjury applies, along with the common grounds for refusing testimony. ${ }^{112}$ In addition, documents, and opinions of experts may be used as evidence, although, to cut back procedural costs, an expert on determining the exact amount of damage may only be appointed provided that the defendant advances the costs. ${ }^{113}$ Keeping in mind the potential cost of applying an expert, which can often exceed the damage caused by a minor offense, this restriction still seems to be a disproportionate sacrifice on the altar of cost-efficiency, as it erodes the right of defense and may prevent the establishment and proving of relevant facts. From another perspective, this ban on experts can also be interpreted as the surrender of the punitive power of the state in several cases, whereas without the relevant opinion of an expert, one can sometimes never learn if the damage caused, actually exceeds the minor offense limit and therefore the conduct constitutes a criminal offense.

After the evidential procedure, or in case of proceeding without a hearing as described above, the authority closes the case with a decision on the merits, in which it either terminates the procedure, or establishes the liability of the defendant and imposes a punishment on him or applies a measure. ${ }^{114}$ The costs of the procedure, if they have arisen, shall be borne by the state in case of termination, or by the defendant, should he be held liable. ${ }^{115}$

These decisions are subject to no appeal, but two more forms of legal remedies may be available. Any decision not establishing minor offense liability may be challenged by a complaint, within 8 days from notification. ${ }^{116}$ Upon complaint, the decision is reviewed by the prosecutor who may reject the complaint on the basis of the records, or annul the decision and instruct the authority on taking a new one. ${ }^{117}$ The prosecutor may not, however, alter the contested decision.

If the liability of the defendant has been established, he may ask for his hearing, as noted above provided the decision was taken prior to that. After the hearing of the defendant and taking any further evidential actions, the authority shall annul its previous decision and pass a new one, which, as a result of the evidential process, can be identical to the first decision annulled.

The decision passed after the hearing, provided that it still establishes liability, may be challenged by another form of legal remedy, and obviously the most important one, namely objection, which leads us directly to the next sub-chapter.

\subsection{Procedure by Courts}

Although courts were excluded from minor offense procedure for some 40 years, their roles set forth by Sztv. have remained basically untouched, i.e. they try minor offenses punishable

\footnotetext{
111 Szabs. tv. s. 71 (2)-(3).

112 Szabs. tv. s. 62 (3), 59 (1)-(2), 60.

113 Szabs. tv. s. 64 (1) (3).

114 Szabs. tv. s. 96 (1).

115 Szabs. tv. s. 96 (2)-(3).

116 Szabs. tv. s. 98 (1).

117 Szabs. tv. s. 98 (4).
} 
by confinement at first instance; deal with any other minor offense cases upon the objection of the defendant at second instance; and play a crucial role in the execution process as explained in chapter 6 .

Upon objection, the minor offense authority may decide to agree with the defendant and alter the decision as requested, which happens extremely rarely; deciding not to do so, it shall forward the case file to the court within 8 days. ${ }^{118}$ Any reform in this field, had to be closely followed by the legislature who kept a close eye on the right to fair trial, as this would have been heavily restricted by the proposed provisions of the Concept, as represented in Chapter 2. As such, a compromised solution was finally enacted. The Act provides that the court shall hold a trial if it is expressively requested in the objection, and it may hold a trial if it considers necessary for any reason. ${ }^{119}$ This change indeed helps speed up the procedure by sparing some trials; the new Act, however, inherited one fault from its predecessor, which leads to different problems in the new environment.

In its conclusive order, the court may uphold, alter or annul the decision of the minor offense authority. Discretionary powers of the court have been cut back from multiple angles. In case of fix fines, the amount of the fine may not be challenged in an objection, and may not be altered by the court; courts in some cases, however, take the liberty to change the form of penalty, as represented in Chapter 4. Apart from that, the court may alter the decision of the first instance in favor of the defendant on grounds of reference upon new facts or evidence that were unknown at the time the decision was delivered; and it shall alter the decision in either way, provided that the minor offense authority misapplied the law. ${ }^{120}$ In the latter case, more severe punishment may only be imposed on grounds of new facts or evidence. ${ }^{121}$ These new provisions seem to narrow the scope of equity, as they, in other words, mean that the punishment may not be reduced if no new evidence occurred and the minor offense authority did not violate any legal provisions. This appearance is deceptive, for in practice, courts consider excessive, disproportionate punishments an infringement of the substantive law provisions on imposing penalty, which leads to the alteration of the decision; hence these restrictions, in fact, only mean a ban on de minimis alteration. ${ }^{122}$

The real problem here is that both acts provide very few grounds for annulment. ${ }^{123}$ The court shall annul the decision only when it was delivered by a member of the minor offense authority excluded by the law, or if the authority exceeded its jurisdiction. If the decision of first instance is unfounded (i.e. the authority failed to locate, collect and support the evidence that could otherwise be collected), instead of annulling the decision and instructing the authority on the repetition of its procedure, the court may only uphold or change the decision. The unfounded nature leaves the court two equally arguable options: it may, upon its own initiative, hold a trial, hear those witnesses the minor offense authority failed to hear, etc., and pass an order supported by the evidence thus gained; or it may be on the view that no burden of proof shall be borne by the court due to its neutral position, therefore it alters the decision and terminates the procedure without any further consideration. The conclusive order of the court is the second instance decision in the minor offense case, and

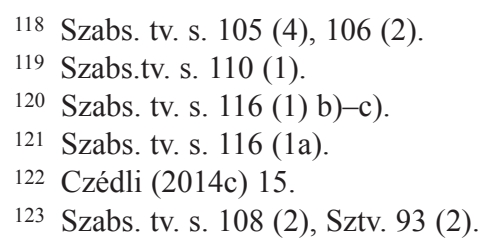


is not subject to any legal remedy, entailing that the first option endangers the right to a fair trial and legal remedy (rights deriving from the constitution!), as in this case the evidential procedure of the court may not be, on any ground, challenged. The second option does not violate fundamental rights, but leads to impunity due to the failure of the minor offense authority. ${ }^{124}$

As for the first instance jurisdiction of the district courts, the scope of minor offenses punishable by confinement has slightly expanded, ${ }^{125}$ but the typical ones are still thefts and frauds of a minor offense value (sub Ft 50001), illegal prostitution and driving whilst under a driving ban. For these minor offenses, the report shall be submitted or forwarded to the police which, in practice, carries out a summary investigation. ${ }^{126}$ This procedure is not called an investigation, but a 'preparatory process' to emphasize the distinction from criminal procedure as usual. General provisions of this preparatory process, on the procedure of minor offense authorities apply; the aim thereof is to collect evidence, and decide on terminating the procedure or submitting the file to the court for further proceedings. Neither this legal instrument, nor its detailed provisions bring much novelty in comparison to the previous act, however, the Szabs. $t v$. made preparatory process compulsory for any minor offense punishable by confinement, unlike the Sztv. that applied it only to minor offenses against property. ${ }^{127}$ This was a change most welcome by courts, whereas it spared them at least the duty of collecting evidence; a task otherwise incompatible with unbiased and fair trial.

The prosecutor does not play any role in the procedure, apart from deciding over any complaints filed during the preparatory phase. ${ }^{128}$ The case file is submitted to the court by the police directly, followed by no formal indictment, merely a summary report that includes the 'data and the findings' of the police. ${ }^{129}$ This practically places the police in the prosecutor's position, though its powers are limited. The Act provides the court with a new and useful option: it can impose a penalty outside confinement or community service work or apply a measure without holding a trial, provided that the 'facts are clear and the hearing of the defendant, the witness, the victim or the expert is unnecessary'. ${ }^{130}$ It is important to see that these rules do not require neither a confession by the defendant, nor any motion or consent from either side. It is a matter of discretion, whether the 'facts are clear' or not, however, the practice of the courts tends to apply this form of omission of trial whenever the documentation of the preparation procedure seems to support the responsibility of the defendant, and seems not to justify any stricter penalty than a fine. Highly burdened police organs usually do not use more resources on minor offense proceedings than ultimately necessary, so in several cases courts equally burdened must try the case to solve the contradictions of the preparatory file. Despite this, the overwhelming majority of minor offense cases punishable by confinement are now administered without holding a trial. This truly helps in speeding up the procedure.

124 Czédli (2014c) 13-14.

125 Chapter XXIII of Szabs. tv.

126 Szabs. tv. s. 117.

127 Sztv. s. 128/A.

${ }^{128}$ In addition to this, the prosecutor may also challenge the final decision of the minor offense authority by a special and rare form of legal remedy, as he exercises power over public administration in general.

129 Szabs. tv. s. $117(5)$.

130 Szabs. tv. s. 118 (1). 
The order of the court rendered in absentia is subject to no appeal, but to another form of legal remedy: the defendant or his representative may request a trial within 8 days. ${ }^{131}$ It should be noted that neither the victim, nor the police in its quasi-prosecutor position have such a right. Upon this motion, the court shall hold a trial on which the representative of the police may be present. If the defendant (or his representative) fail to attend the trial, his request at trial shall be considered withdrawn, and the order becomes final. ${ }^{132}$ The trial itself, either held upon request, or on the court's own initiative, is not in all details regulated by the Act; and does, although simpler and faster, resemble a criminal trial.

If the Act does not provide otherwise, the defendant, his representative, the police and, considering the damages, the victim may submit an appeal against any order promulgated at the trial within 8 days, as seen already in sub-chapter 5.1.133 Although it is still unclear if orders not promulgated may be subject to an appeal, it is crucial to see that this does not undermine the defendant's right to a fair trial and legal remedy, since any decision establishing his liability is either subject to a request at trial as written above, or to an appeal. On grounds provided by the law, the court may decide anytime on terminating or suspending the procedure, which orders may be promulgated at trial; or these decisions may be without a trial. The position of the police is unique, as it may not request a trial; it may, however, appeal, which gives the impression as if the legislature were uncertain of the role the police in these procedures should play.

Tribunals adjudicate on appeals in a written procedure, their order is subject to no further legal remedy. ${ }^{134}$ The court of second instance may, acting in panel, uphold, alter or annul the order of the district court. ${ }^{135}$ When altering the decision and in case no appeal from the police is present, the tribunal may not impose any punishment more severe than that imposed by the court of first instance. This rule mutatis mutandis applies to the court of first instance too, when holding a trial upon request, i.e. any penalty or measure may only be more severe than that imposed in the order rendered in absentia if new evidence arises at trial. ${ }^{136}$ The annulling powers of the tribunals, unlike those of the district courts ruling on objections, are unrestricted; unfounded nature or major infringement of procedural provisions lead to a repetition of the first instance procedure.

Finally, the Szabs. tv., unlike criminal procedure, provides only one extraordinary remedy: retrial. Grounds for retrial may be new evidence, violating the principle ne bis in idem, false or falsified evidence used in the basic case, criminal offense committed by a member of the court or the minor offense authority therein, or which is most common, if the conduct considered a minor offense in the basic case constitutes a criminal offense. ${ }^{137}$ Retrial may be initiated only within one year after the basic decision has become final. ${ }^{138}$

131 Szabs. tv. s. 119 (1).

132 Szabs. tv. s. 119 (2) (3). The defendant shall be warned of this consequence in the order and in the subpoena.

133 Bisztriczki (2012) 109.

134 Szabs. tv. s. 122 (1), 123 (1a).

135 Szabs. tv. s. 123 (1).

136 Szabs. tv. s. 121 (1) (3), 120 (7).

137 Szabs. tv. s. 127 (1).

138 Szabs. tv. s. 127 (3). 


\subsection{Summary and Accelerated Procedures}

Beside the ordinary first instance procedures of the minor offense authorities and the courts, the Act provides two high-speed options as well.

Summary or on-the-spot procedure is carried out by minor offense authorities, usually by the police, in case of in flagrante delicto. It results in some summary sort of plea bargaining: if the defendant agrees to the amount of fine offered by the police officer, and acknowledges the commitment of the minor offense, the form on a summary fine undersigned by the defendant is subject to no appeal. ${ }^{139}$ Usually both the defendant and the officer are interested in this type of procedure. The maximum amount of the summary fine has been increased by the Szabs. $t$., but it is still only the one third of the maximum penalty imposable in a normal procedure, ${ }^{140}$ and in most cases it is way closer to the minimum of $5000 \mathrm{Ft}(\sim 16 €)$. If the minor offense is punishable by a fix fine, then it applies to the summary procedure as well, the amount of the fine is, however, always the half of the 'normal' amount. As for the officer, the police are also more interested in filling in a small form on the fine than to start a formal procedure that can last for months, which probably also helps the bargain.

The new Act introduced two remarkable changes considering summary fines: now the police may impose a summary fine for literally any minor offense, even if it is otherwise punishable by confinement; ${ }^{141}$ and if the defendant fails to pay the fine, no milder rules apply on execution any more, as we can see in the next chapter.

Although the default rules of minor offense procedure are as I presented in the previous sub-chapters, the practical significance of summary fines can easily be demonstrated by the fact that they are imposed in approximately 2000000 cases every year (in a country of 10 million inhabitants), while there are less than 700000 'normal' minor offense procedures. ${ }^{142}$

Accelerated procedure is different and more controversial. It is not a new instrument either: the Sztv. introduced custody for perpetrators of minor offenses punishable by confinement in case of in flagrante delicto, which rules have remained unchanged. ${ }^{143}$ In these cases the police may take the defendant into custody; having done so, it shall bring him to trial within 72 hours, as the custody may not last longer than this period. ${ }^{144}$ If there is no obstacle, the court holds a trial, at which the participation of a legal representative and the police is compulsory, ${ }^{145}$ and in its order, it terminates custody, in cases where no confinement has been imposed. The court may also prolong custody by up to 10 days provided that the order imposing confinement has not become final (due to an appeal), and the court has 'grounds to believe that the defendant would commit another minor offense punishable by confinement.' 146 This provision can, in practice, make any appeal pointless, as a confinement of 10 days would be executed before any second instance decision could have been passed.

\footnotetext{
139 Szabs. tv. s. 99 (3).

140 Szabs. tv. s. 99 (2).

141 Szabs. tv. s. 39 (1).

142 Bisztriczki (2012) 263.

143 Sztv. s. 77 (1); Szabs. tv. s. 73 (1).

144 Szabs. tv. s. 73 (2), 124 (1).

145 Szabs. tv. s. 124 (3), 125 (1).

146 Szabs. tv. s. 73 (3)-(4).
} 
While fast retribution always has a greater deterring effect, there has been much criticism of this instrument, mainly because police organs tend to apply custody in case of in flagrante delicto with no consideration to the severity of the minor offense and the possible punishment that can be imposed in the particular case. This often means that the defendant spends 2 or 3 days detained, only to get a warning or a minimal fine from the court, which raises serious doubts about the proportionality and usefulness of accelerated procedures. According to an analysis of the accelerated minor offense procedures at the District Court of Szeged, defendants spend 41 hours in custody on average, and only $35 \%$ of them are punished by confinement, meaning that in almost two third of these cases, deprivation of personal liberty was unnecessary. ${ }^{147}$ The lack of proportionality can also be interpreted as an infringement of the right to personal freedom. ${ }^{148}$

\section{EXECUTION}

It is obvious for any procedural code that, unless the law provides otherwise, any decision may or shall be executed only after the decision has become final. This is a point, however, where the Szabs. $t$. lures us into thinking that there can be some circumstances when it could be questionable when a decision can be construed as being final. The Act provides that any decision is final on the subsequent day to the last day of the period open for legal remedy; on the day of the withdrawal of any motion aiming at a legal remedy; or on the day of its communication when the decision is subject to no legal remedy. ${ }^{149}$ The latter is totally senseless.

By the term 'final' I mean, as Hungarian jurisprudence usually does, two things: the decision may not be challenged by any ordinary legal remedy any more (the decision is definite); and it has the effect res iudicata, i.e. the facts established in it are deemed true. The latter only applies to some judicial decisions on the merit of the case, so the universal effect of a decision's becoming final is the exclusion of any further legal remedy. According to any other Hungarian act of law, a decision is final on the day it is promulgated or passed, provided it is subject to no (further) legal remedy, which raises the question, what effect does a minor offense decision subject to no appeal have before its communication, and what happens upon the failure thereof? Logic says that if the right of appeal is, even by interpretation, excluded, then the decision is final from the very moment it is born, as that is what final means. Ironically, Szabs. $t v$. provides otherwise. It is not a mere question of philosophy, courts strictly and grammatically following the said provision can often face the situation that the defendant changes his address, becoming unavailable, in which case all they can do is to wait till the case becomes statute-barred. This is probably not the most expedient and efficient way of proceeding that the legislature dreamed about. The other options are either acting contra legem, or evading establishing the day of becoming final whenever the court considers it possible. It is an arguable practice which is founded on the fact that the Act does not have any expressed provision on establishing that day and noting it in the file. ${ }^{150}$

147 Szabó (2014) available at <http://www.mabie.hu/node/2162> accessed on 11 February 2015 6-7.

148 Mándi (2013) 42, 45.

149 Szabs. tv. s. 138 (1).

150 Czédli (2014c) 21-23. 
If, having overcome any possible difficulties, the decision is final, then the system of execution is basically quite simple. Minor offense authorities execute their own decisions, while any punishment imposed by the court shall be executed by the district offices. ${ }^{151}$ Should the defendant fail to pay the fine or fulfill the community service work, these punishments shall be transformed into confinement by the court, upon motion of the minor offense authority. ${ }^{152}$ Confinement is executed in selected penitentiaries.

If punished by a fine, the defendant may choose to redeem it by community service work that the labor offices shall provide him with. ${ }^{153}$ This is one major achievement of the new Act, for under Sztv., fines were executed by local notaries that may or may not have provided community service work depending on the actual situation of the local council, raising serious doubts about equality before the law. ${ }^{154}$

By its entering into force, the Szabs. $t v$. inherited all procedural rules of its predecessor considering transforming fines into confinement. ${ }^{155}$ As the new Act, on the other hand, extended the scope of these transformations to juveniles and to summary fines, the number of these cases radically increased. ${ }^{156}$ These decisions involving deprivation of personal liberty fall exclusively within the jurisdiction of courts which suddenly had to hold ten times more minor offense trials, than before. Without any additional funds provided, courts lacking enough (administrative) judges, court rooms, officials, etc. could hardly deal with such pressure. The unsustainable situation was finally solved by the legislature by turning the obligation of trial to the right to trial, meaning that the court decides on the basis of the case-file, and hears the defendant only upon his expressed motion. According to provisions in force, the court shall notify the defendant of the motion on transformation and his right to ask for trial within an 8-day limitation period, after which, unless requested otherwise, it decides without holding a trial. ${ }^{157}$

Transformation procedure is more than mere automatism. Szabs. $t v$. sets several obstacles to confinement, like disability or pregnancy; ${ }^{158}$ should any of these factors be proven, the court omits transformation, in which case the fine shall be subsequently executed as taxes. ${ }^{159}$ The procedure also involves elements of a special legal remedy, because the court shall examine the legality of the basic proceedings and its execution, and upon detecting any violation of the law, it shall annul the final decision or instruct the minor offense authority on continuing execution. ${ }^{160}$ Practical experiences indicate that police officers still quite often fail to properly fill in the short form on imposing a summary fine, which finally entails impunity, as the first instance procedure may only be repeated in a

151 Szabs. tv. s. 141 (2)-(3), 144 (2).

152 Szabs. tv. s. 12 (1), 15, 141 (6).

153 Szabs.tv. s. 13.

154 Sztv. s. 111 (5).

155 See Sztv. s. 102/A and Szabs.tv. s. 141 in force prior to 01.09.2013.

156 The number of minor offense cases at the local courts altogether has increased from less than 10000 per month to above 30000 , which means a caseload of about 400000 every year. (Data gained from the report 2014.OBH.XXI.B.1.15/8 on the annual statistics of the Hungarian courts of 2013, 16; available at: http://www.birosag.hu/sites/default/files/allomanyok/statisztikai_adatok/ugyforgalmi_ elemzes_2013_eves.pdf.)

157 Szabs.tv. s. 141 (9) and (12); Act XCIII of 2013 s. 167.

158 See Szabs.tv. s. 10 for details.

159 Szabs.tv. s. 141 (7) and (17).

160 Szabs.tv. s. 141 (13) d)-e). 
normal procedure. The Act does not provide any possibility on re-imposing a summary fine after annulment. In my opinion, annulment of a summary fine does not prevent police authorities from starting a normal minor offense procedure, although they definitely should not impose a higher fine in this case; police, however, follow the opposite practice and consider the court's decision on annulment a final termination of any proceedings. It may have the impact that any defendant familiar with this practice can willfully choose not to pay the summary fine until it has been transformed, buying time, trusting in a possible annulment, having nothing to lose.

Confinement replacing fine or summary fine, just like confinement as a punishment, is executed by the minor offense authorities in penitentiaries with the only, yet remarkable, difference that the defendant may still any time pay the fine to avoid the actual execution of confinement. ${ }^{161}$ Any statistics on the desired improved efficiency of fine execution is unknown to me, however, it seems likely that now significantly more summary fines are paid indeed, at latest before the actual commencement of the confinement, than under Sztv.

Criticism of the execution system in force may be on either substantive, or procedural grounds. As for the former, efficient execution obviously needs some form of coercion from the state, however, the costs of detention exceed the amount of the fine, not to mention the costs of the proceedings, which may undermine the rationality of the current system.

Procedural provisions are still bureaucratic and inaccurate. By bureaucratic, I mean that the legislature really should have considered simply letting the courts decide on transforming without holding a trial and notifying the defendant of this before providing a right to request for trial, as a legal remedy against that decision, thus sparing the time and costs of contacting the defendant twice in the ten-thousands of these cases. In addition to the question of annulment, inaccuracy led to two waves of conflicts of competence, because the original text did not have any provisions on competence considering execution cases, then the amendment on procedural regulations introduced controversial rules to this. ${ }^{162}$

\section{FINAL WORDS}

If Alexandra Natapoff described felonies as the mere tip of the iceberg in her essay on misdemeanors, ${ }^{163}$ then minor offenses are not only the hidden bottom, but the entire seabed. As her research showed the reduced 'significance of law and evidence, and therefore fault, at the bottom of the penal pyramid' and suggested various amendments, ${ }^{164}$ we can apply her description to the Hungarian law and practice of minor offenses, for all social, historical, economic and legal differences even.

When evaluating Hungarian minor offense law as a whole and in its current form, we shall never forget that it is not a part of the criminal law, therefore all guarantees of criminal proceedings may not be required. Conduct constituting a minor offense represent a reduced risk to others and society in general, thus they are punished with less severe sanctions. Perpetrators are not simply considered not guilty by the law, but they are indeed much less guilty in a moral sense. Some minor offenses, especially violating some lesser traffic rules are followed by no contempt by the public, while criminal offenses are always considered despicable. Minor offense procedure, however, strongly resembles criminal procedure, as

\footnotetext{
161 Szabs.tv. s. 141 (14).

162 Czédli (2014b) 43-58.

163 Natapoff (2012) 102.

164 Natapoff (2012) 159-162.
} 
the basic situation is the same: the individual is facing the punitive powers of the state, including a possible deprivation of his freedom. Minor offenses are indeed petty, but not petty enough to avoid incarceration in certain cases. Conviction does not create a criminal record, even if it or its execution includes confinement, but it still may have various effects on a subsequent criminal procedure from being an aggravating circumstance to changing the exact legal classification.

Altogether at least 2.5 million minor offense procedures start in this country of a population of ten million, thus they represent a huge workload and cost on public administration and judicial system, so the legislature must carefully consider the effects of any amendments. Alternatively, this huge number means one more thing: while most people never commit a criminal offense, and get involved in criminal proceedings as a witness or victim at most, it is hard to spend a lifetime without ever perpetrating a single minor offense, usually a traffic one. ${ }^{165}$ Every citizen has interactions with public administration in numerous ways, but most of them only see the sanctioning, punishing face in a minor offense procedure, and this is the only direct impression they gain.

When governing this field, the legislature of any country needs to find a delicate balance between procedural safeguards and the equally acceptable demand on low-cost, expedient and efficient procedure. The only problem is that we are facing a paradox. In the words of Marianna Nagy, the question is, what compromises can we accept of procedural guarantees, as budget-friendly legal solutions always derive from giving up one or more of them. ${ }^{166}$ When drawing the overall balance of Hungarian minor offense procedure, we shall check if it has reached the highest possible efficiency and if it has maintained at least the lowest acceptable level of procedural rights in the meantime. In my opinion, which may be challenged of course, the answer is 'no' to the first question, and a weak 'yes' to the second. I do not think, there is much room to accelerate the proceedings of minor offense authorities, if not by excluding legal remedy against some more decisions (like suspension, or termination even) or by abolishing or reforming mediation. The role and procedure of courts should, however, be rethought. Even without any conceptual changes, the legislature had better draft precise and clear provisions on appeal, widen the applicability of cassation when deciding on an objection, rationalize rules on a decision's being final, and simplify the transformation procedure even further, to solve the most urgent issues presented in the previous chapters.

The core of substantive regulations is a result of ideology and criminal policy that is not up to this article to evaluate. The new Act had fewer changes at this level; some of them proved to be clearly positive, like the introduction of community service work as a penalty, the wider applicability of the driving ban or the general right to redeem any fine by community service work. Fixed fines, restrictions on repeaters, the radical increase of maximum fines and above all, the confinement of juveniles are, however, arguable, even if the latter is no novelty at all.

The enacting of the new code was justified by the need for an expedient and more efficient procedure, as we could have seen in Chapter 2. Lacking proper statistics, it is hard to decide, whether this goal was achieved. If we consider the time that passes from the filing of the report till the payment of the fine or execution of the confinement, procedures,

165 Not to mention latency: willful traffic infringements are usually committed (at least meant to be committed) in the absence of the police, and the vast majority of them remains unnoticed.

166 Nagy (2012) 224. 
on average, must have become faster. Most of this increase of speed is, however, due to the different system of executing fines, all other changes show minimal or controversial relevance. If we focus only on the duration of the proceedings till a final decision is delivered, that might still be shorter, but the difference is insignificant. And finally, if we consider the possible result the new Act could have achieved, there is even less space for optimism.

This article presented the provisions of Szabs.tv. as they are in force today. What the future of legislation holds, is unknown. There is no perfect law and no mistake that cannot be mended; all it takes is a bit more of consideration from the realization of the problem to the proper means of solution.

\section{LITERATURE}

Árva, Zs., 'Merre tovább, szabálysértési jog?’ (2012) 9 Új Magyar Közigazgatás 46-53.

Belcsák, R. F., Lassú evezőcsapásokkal a kihágási büntetőjog felé, avagy gondolatok az új szabálysértési törvényhez' (2013) 9/1 Iustum Aequum Salutare: Jogtudományi folyóirat 163-179.

Bisztriczki, L., Kántás, P., Az új szabálysértési törvény magyarázata - Gyakorlati kérdések és válaszok a szabálysértési jog köréböl (HVG-ORAC 2012).

Czédli, G., 'A szabálysértési jogorvoslati rendszer és bíráskodás rövid története' (2014a) at <http:// www.mabie.hu/node/2165>

Czédli G., Czédli-Deák, A., 'A kijelölő végzés margójára' (2014b) 62/10 Belügyi Szemle 43-58.

Czédli, G., 'A szabálysértési jog jogorvoslati rendszerének aktuális kérdései’ (2014c) 8/1 De iurisprudentia et iure publico 9-28.

Mándi, V., 'Alkotmányossági aggályok a szabálysértési őrizetbe vétel gyakorlata kapcsán.' (2013) 1-2 Büntetöjogi Szemle 42-47.

Máthé, G., 'Critical Remarks on Hungarian Law Regulating Minor Offences' (2006) 1 Studia Iuridica Caroliensia 131-150.

Nagy, M., 'Quo vadis Domine? Elmélkedések a szabálysértések helyéről a 2012. évi szabálysértési törvény kapcsán’ (2012) 67/5 Jogtudományi Közlöny 217-226.

Nánási, I., 'A szabálysértési törvények kapcsolata más törvényekkel egy bírósági eljáráson keresztül' (2012) 60/12 Belügyi Szemle 50-69.

Natapoff, A., 'Misdemeanors' (2012) 8 Loyola Law School Los Angeles Legal Studies Paper 100163.

Szabó, Sz., 'Gondolatok a szabálysértési őrizetről és a gyorsított szabálysértési eljárásról' (2014) at $<$ http://www.mabie.hu/node/2162> 